\title{
VARIAN GENETIK Sardinella lemuru DI PERAIRAN SELAT BALI
}

\section{GENETIC VARIANCE OF Sardinela lemuru IN THE BALI STRAIT WATERS}

\author{
Gde Raka Angga Kartika ${ }^{{ }^{*}}$, Aida Sartimbul ${ }^{2}$, Widodo ${ }^{3}$ \\ ${ }^{1}$ Fakultas Kelautan dan Perikanan Universitas Udayana, Bali \\ ${ }^{2}$ Fakultas Perikanan dan Kelautan Universitas Brawijaya, Malang \\ ${ }^{3}$ Fakultas Matematika dan IImu Pengetahuan Alam Universitas Brawijaya, Malang \\ "Corresponding author email: raka.angga.k@gmail.com
}

Submitted: 1 Agustus 2016 / Revised: 24 Maret 2017 / Accepted: 25 April 2017

http://doi.org/10.21107/jk.v10i1.1615

\begin{abstract}
Sardinella lemuru is one of the fish species that dominate in the Bali Strait. Identification Sardinella lemuru with the others Sardinella in the Strait of Bali is based on morphological characteristics, whereas genetic identification of Sardinella lemuru in Bali Strait has not been done and variations genetic also unknown. This research aims to ascertain the type of Sardinella lemuru in the bali strait and Determine genetic variation and kinship based on cytochrome oxidase subunit (COI) gene. The method is performed by isolating DNA from fish organs and the results are amplified by the COI gene sequencing then performed to obtain the data sequence of Sardinella lemuru Bali Strait and analysed using the program MEGA 5.2. Results showed that lemuru in Bali Strait is Sardinella lemuru species with the degree of similarity BLAST analysis of 98-100\%. 11 samples sequence of lemuru forming two large clad. The results also showed that the species of Sardinella lemuru and Sardinella longiceps different species with genetic distance> 0,019.
\end{abstract}

Keywords: COI, Sardinella lemuru, Bali Straits

\section{ABSTRAK}

Sardinella lemuru merupakan salah satu spesies ikan yang mendominasi di perairan Selat Bali. Identifikasi Sardinella lemuru dengan sardinella lain di perairan Selat Bali hanya dibedakan berdasarkan secara morfologi, sedangkan identifikasi genetik belum pernah dilakukan dan variasi gentetik juga belum diketahui. Penelitian ini bertujuan memastikan jenis Sardinella lemuru di perairan Selat Bali dan mengetahui variasi genetik dan kekerabatannya berdasarkan gen Cythocrome oxidase sub unit 1 (COI). Metode yang dilakukan adalah dengan mengisolasi DNA dari organ tubuh ikan lemuru dan hasilnya diamplifikasi dengan gen COI, kemudian dilakukan skuensing untuk mendapatkan sekuen data ikan lemuru perairan Selat Bali dan urutan basa hasil skuensing dianalisis menggunakan program MEGA 5.2. Hasil menunjukan bahwa ikan lemuru di Selat Bali termasuk kedalam spesies Sardinella lemuru dengan tingkat kesamaan analisis BLAST adalah sebesar 98-100\%. 11 sampel skuen ikan lemuru membentuk 2 kelompok besar. Hasil penelitian juga menunjukkan bahwa spesies Sardinella lemuru dan Sardinella longiceps merupakan speies ikan yang berbeda dengan jarak genetik >0,019

Kata Kunci: COI, Sardinella lemuru, Selat Bali

\section{PENDAHULUAN}

Perairan Selat Bali merupakan wilayah perairan yang memisahkan antara Pulau Jawa dan Bali. Perairan ini memiliki potensi perikanan yang sangat besar dan keunikan tersendiri. Beberapa komoditas perikanan yang sering dijumpai di Selat Bali adalah ikan lemuru (Sardinella lemuru), tongkol dan ikan layang. Sumberdaya perikanan lemuru merupakan sumberdaya perikanan yang paling dominan dan bernilai ekonomis di 
Selat Bali sehingga komoditi tersebut paling banyak dieksploitasi oleh nelayan yang bermukim di sekitar Selat Bali. Hal ini yang menyebabkan perikanan lemuru mempunyai peranan yang cukup penting bagi kehidupan masyarakat setempat.

Nilai penting komoditas perikanan lemuru di selat bali dapat dilihat dari data tangkapan ikan yang didominasi oleh jenis ikan lemuru. Berdasarkan data pendaratan ikan lemuru di PPI Muncar selama 10 tahun terakhir terlihat bahwa puncak produksi terjadi pada tahun 2006 dan 2007 yang mencapai lebih dari 50.000 ton. Namun dalam kurun beberapa tahun terakhir produksi perikanan lemuru mengalami penurunan yang signifikan. Penurunan ini diduga terkait dengan perubahan kondisi lingkungan dan penangkapan yang sudah sangat berlebihan (Susilo, 2015). Penangkapan yang berlebih dengan menggunakan armada purse seine pada komoditas ikan lemuru di selat bali dapat mengancam kelestarian sumberdaya ikan itu sendiri yang pada giliran berikutnya menyebabkan turunnya produksi atau bahkan kepunahan.

Pengetahuan tentang aspek biologi dan ekologi ikan lemuru sangat diperlukan dalam pengelolaan pelestarian sumberdaya ikan lemuru. Selama ini pengelolaan sumberdaya ikan lemuru pada umumnya hanya ditekankan pada pengertian yang sempit yaitu kelimpahan dan ukuran ikan yang akan ditangkap. Akibat dari fokus jangka pendek tersebut, maka perspektif biologi dari pengelolaan sumberdaya ikan lemuru lebih didominasi oleh pengetahuan tentang dinamika populasi dan ekologi dibandingkan dengan pemahaman tentang aspek genetika populasi (Noor, 2008). Aspek genetika ikan merupakan salah satu bagian terpenting dalam mengetahui kekerabatan dan varian genetic suatu populasi ikan di suatu daerah. Salah satu metode yang dapat digunakan untuk mengetahui varian genetic dan kekerabatan pada hewan adalah menggunakan gen penyandi yaitu gen cytochrome oxidase sub unit I (COI)

Gen cytochrome oxidase sub unit I (COI) merupakan salah satu gen dalam mitokondria yang dapat digunakan dalam studi karakter genetik maupun filogeni dari hewan. Ukuran dan struktur dari gen cytochrome oxidase subunit 1 (COI) telah menjadi fokus pada analisis kelompok hewan dan studi evolusi sebagaimana diperlihatkan pada studi karakter genetik maupun pola-pola evolusi pada hewan (Tubaro dan Lijtmaer, 2002). Gen COI merupakan salah satu region target dalam teknik DNA Barcoding karena dinilai efektif untuk digunakan sebagai diskriminan kelompok hewan (Costa et al., 2007). Penggunaan gen COI untuk membedakan species sudah dilakukan pada beberapa jenis spesies hewan contohnya pada udang mantis, kerang, ulat sutra, serangga, sapi dan beberapa jenis species ikan. Menurut Buhay (2009) bahwa COI merupakan salah satu metode yang sangat membantu untuk mengidentifikasi kekerabatan pada spesies hewan dan ikan. Herbert et al. (2003), juga menyatakan bahwa Gen COI dapat membantu sistem bioidentifikasi pada berbagai jenis hewan dan mampu memberikan jawaban terhadap kekerabatan dalam spesies mencapai $100 \%$. Divya et al., (2009).

Penurunan jumlah populasi ikan lemuru dapat menyebabkan variasi genetik akan berubah pada masa selanjutnya. Kecilnya populasi ikan lemuru yang tersisa akan mengarah terjadinya silang dalam yang berakibat kepada perubahan keragaman genetik. Dunham (2002) menjelaskan bahwa variasi genetik penting untuk kelangsungan hidup jangka panjang suatu species dan juga dapat menjamin kekuatan suatu spesies atau populasi dengan memberikan spesies atau populasi tersebut kemampuan untuk beradaptasi pada perubahan lingkungan. Sampai saat ini publikasi tentang studi kekerabatan dalam spesies Sardinella lemuru di Selat Bali masih sangat sedikit, bahkan dengan metode $\mathrm{COI}$ belum pernah dilaporkan, sehingga perlunya mengetahui varian genetic Sardinella lemuru di Selat Bali sebagai data base untuk berbagai kepentingan seperti manajemen penangkapan ikan lemuru di perairan Selat Bali dan berbagai kepentingan lain.

\section{MATERI DAN METODE}

Pengambilan sampel ikan lemuru dilakukan di Pelabuhan Perikanan Muncar Banyuwangi, Jawa Timur dan Tempat Pendaratan Ikan Kedonganan Badung, Bali. Analisis DNA berdasarkan gen Cytochrome Oxidase Sub Unit I dilakukan di Laboratorium 
Biomolekuler Fakultas MIPA Universitas Brawijaya Malang.

Bahan - bahan yang digunakan dalam ekstraksi DNA adalah sebgai berikut: akuadest steril,larutan lysis buffer, ammonium acetate, ETOH 100\%, Etanol 70 $\%$, larutan buffer TE. Metode ekstraksi DNA yang dilakukan mengacu pada metode yang diterapkan oleh Ausubel et al, (2002). Pada penelitian ini menggunakan primer forward (5'- TCAACCAACCACAAAGACGACATTG GCAC -3') sebagai primer pertama dan primer reverse (5'TAGACTTCTGGGTGGCCAAAGAATC A 3') (Jonas, 2011). Amplifikasi dilakukan menggunakan sekuen gen dengan panjang 650 base pair dari COI Fragment. Volume total Mixture PCR : $5 \mu \mathrm{l}$ terdiri dari : Aquabidest : $2 \mu \mathrm{l}$, Primer I : 5'TCAACCAACCACAAAGACGACATTG

GCAC -3' $1 \mu, \mathrm{l}$, Primer II : 5'TAGACTTCTGGGTGGCCAAAGAATC A -3' $1 \mu \mathrm{l}$, Master mix: 5ul, Sampel DNA : $1 \mu \mathrm{l}$. Proses amplifikasi PCR adalah denaturasi pada suhu $94^{\circ} \mathrm{C}$ selama 1 menit, annealing pada suhu $54^{\circ} \mathrm{C}$ selama 30 detik dan pemanjangan pada suhu $72^{\circ} \mathrm{C}$ selama 1 menit dengan jumlah siklus adalah 35 siklus. Pemanjangan terakhir dilakukan pada suhu $72^{\circ} \mathrm{C}$ selama 10 menit. Verifikasi hasil dari analisa PCR dilakukan dengan running electrophoresis menggunakan gel agarose $1,5 \%$. Hasil dari electrophoresis kemudian diamati dengan UV - transiluminator dan difoto sebagai dokumentasi

Hasil dari PCR (band pada gel agarose) harus dimurnikan dengan menghilang protein dan kontaminan lainnya. Hasil PCR dicampur dengan etanol absolute dan NaAcin pda tabung PCR, kemudian dicampur dan di inkubasi pada suhu $20^{\circ} \mathrm{C}$ selama 30 menit. Larutan ini disentrifuse dengan kecepatan maksimum selama 5 menit lalu supernatan dibuang. 750 ul etanol 70\% ditambahkan ke dalam butiran DNA, setelah itu disentrifuse pada kecepatan maksimum selama 3 menit, dan butiran dilarutkan dengan $50 \mathrm{ul} \mathrm{dd}_{2} \mathrm{O}$.

Urutan basa dari hasil skuensing DNA diperiksa dengan menggunakan gene scane ABI. Urutan dicek kebenarannya berdasarkan kemiripan dengan $\mathrm{COI}$ dari genus Sardinella di gen bank dengan menggunakan metode BLAST. Software Mega 5.2 digunakan untuk mengetahui indeks kemiripan di antara sampel. Kemiripan berdasarkan panjang DNA mengikuti metode dari (Nei dan Kumar, 2000), yang diperoleh dengan membagi jumlah perbedaan nukleotida dengan jumlah total nukleotida pembanding.

Basa nukleotida hasil sekuensing kemudian dibandingkan dengan skuen Gen Sardinella lemuru dan Sardinella longiceps dari daerah lain. Sekuen gen $\mathrm{COI}$ yang digunakan sebagai pembanding diperoleh dari gen bank $\mathrm{NCBI}$ (Tabel 1). Pohon filogenetik akan dibangun menggunakan software Mega 5.2 berdasarkan jarak DNA dari analisa sebelumnya. Rekonstruksi dari sejarah evolusi gen dan spesies merupakan salah satu hal terpenting dalam evolusi molekuler. Data ini sangat penting untuk memahami mekanisme evolusi dari satu spesies (Nei and Kumar, 2000).

Tabel 1. Sekuen gen COI Sardinella lemuru dan Sardinella longiceps dari Gen Bank

\begin{tabular}{llc}
\hline NO & \multicolumn{1}{c}{ Lokasi } & Gen Bank Acc numb \\
\hline $\mathbf{1}$ & Laut China Selatan (MBCSC-2711073) & EU5955255.1 \\
$\mathbf{2}$ & Laut China Selatan (MBCSC-2711073) & EU5955256.1 \\
$\mathbf{3}$ & China (FSCS327-06) & EF607505.1 \\
$\mathbf{4}$ & China (FSCS328-06) & EF607504.1 \\
$\mathbf{5}$ & Filipina (2) & HQ231366.1 \\
$\mathbf{6}$ & Filipina (3) & HQ231365.1 \\
$\mathbf{7}$ & Filipina (4) & HQ231364.1 \\
$\mathbf{8}$ & Selat Taiwan (1) & KX2544.86.1 \\
$\mathbf{9}$ & Selat Taiwan (1) & KX2544.86.1 \\
$\mathbf{1 0}$ & S. longiceps (COML-111) & KF36899.1 \\
$\mathbf{1 1}$ & S. longiceps (IOBML) & FJ384694 \\
\hline
\end{tabular}




\section{HASIL DAN PEMBAHASAN}

Keragaman genetik Sardinella lemuru dikaji berdasarkan gen cythocrome oksidase 1 (COI). Gen ini dipilih karena fragmen pendek COI dapat digunakan sebagai penanda variasi yang secara akurat dapat mengidentifikasi berbagai macam hewan sampai tingkat spesies (Hebert, 2003). Gen $\mathrm{COI}$ juga sangat tepat untuk mengetahui keragaman genetik yang terdapat pada suatu spesies atau antar populasi. Panjang gen COI yang berhasil teramplifikasi adalah \pm 650 bp (base pair), ini dibuktikan dengan uji kualitatif menggunakan elektroforesis gel agarose (Gambar 1). Dari hasil elektroforesis, 20 sampel ikan lemuru hanya didapatkan 15 sampel yang tampak terlihat jelas pita DNAnya. Hasil sekuensing dapat terbaca dengan baik berkisar antara $650 \mathrm{bp}$. Hasil analisis dengan fasilitas BLAST menunjukkan bahwa ikan lemuru yang diperoleh di Muncar, Banyuwangi dan Kedonganan, Badung dikonfirmasi sebagai spesies Sardinella lemuru. Panjang amplikon gen COI yang di dapat pada penelitian hampir sama dengan panjang gen amplikon Sardinella lemuru yang terdapat pada Gen Bank yaitu sebesar 652 bp. (Zhang, 2011). Beberapa hasil amplifikasi terlihat tidak jelas atau samar, hasil yang samar dapat ini disebabkan oleh konsentrasi DNA yang terkandung rendah atau masih terkontaminasi dengan RNA dan protein.

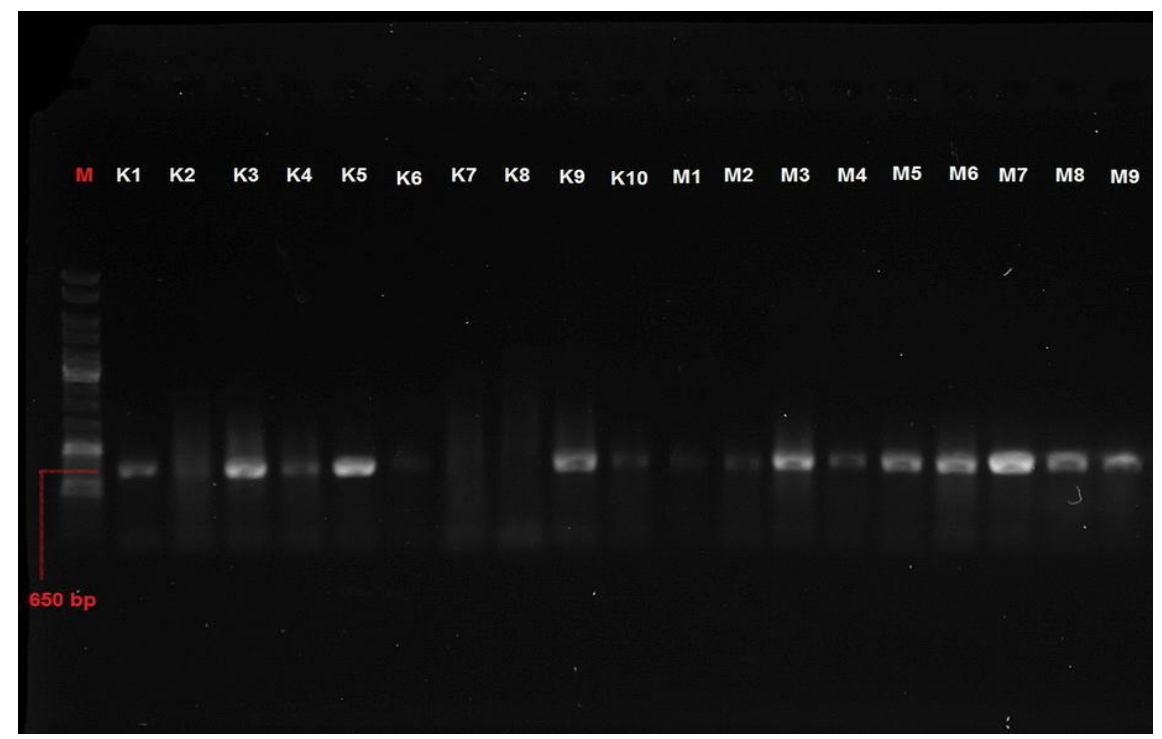

Gambar 1. Hasil Amplifikasi Gen COI Sardinella Lemuru Pada Gel Agarosa 1,5\%

Mutasi gen merupakan faktor yang menyebabkan timbulnya keanekaragaman genetik yang berakibat pada timbulnya keanekaragaman dalam kehidupan. Dilihat dari sudut penyebabnya, mutasi dikelompokkan menjadi dua jenis yaitu mutasi spontan dan mutasi terimbas. Mutasi spontan merupakan mutasi yang terjadi pasa kondisi alami selama proses replikasi, perbaikan, dan rekombinasi DNA. Mutasi terimbas adalah mutasi yang disebabkan oleh agen agen lingkungan spesifik (Sofro 1994). Mutasi substitusi merupakan jenis mutasi gen dimana basa nukleotida berubah menjadi bentuk basa lain dalam urutan DNA yang dapat menyebabkan terjadinya evolusi. Mutasi substitusi dibagi ke dalam dua jenis yaitu transisi dan tranversi. Transisi adalah pengubahan antara $A$ dan $G$ (purin) atau antara $C$ dan $T$ (pirimidin) (Wijana dan Mahardika, 2010) Tranversi adalah pengubahan antara purin dengan pirimidin. Substitusi transisi ditunjukkan oleh angka yang bercetak tebal sedangkan substitusi tranversi ditunjukkan oleh angka yang bercetak miring (Tabel 2) Mutasi inilah yang menyebabkan variasi genetik pada suatu organisme. 
Tabel 2. Matriks Probabilitas Substitusi Nukleotida Spesies Sardinella lemuru

\begin{tabular}{lllll}
\hline & $\mathrm{A}$ & $\mathrm{T}$ & $\mathrm{C}$ & $\mathrm{G}$ \\
\hline $\mathrm{A}$ & - & 2.58 & 2.7 & 12.47 \\
$\mathrm{~T}$ & 1.92 & - & 28.1 & 1.6 \\
$\mathrm{C}$ & 1.92 & 26.85 & - & 1.6 \\
$\mathrm{G}$ & 14.98 & 2.58 & 2.7 & - \\
\hline
\end{tabular}

Berdasarkan analisis yang telah dilakukan diketahui bahwa nilai similaritas dan jarak genetik bervariasi pada kesebelas sampel yang dianalisis (Tabel 3). Sementara hasil analisis jarak genetik skuen ikan lemuru dari gen COI menunjukkan bahwa jarak genetik terdekat adalah $0,0 \%$, yaitu sampel $\mathrm{K} 3, \mathrm{M} 3$, M6, Filipina 2 dan Taiwan 2 dengan memiliki nilai similaritas sebesar $100 \%$. Serta sampel K9 dan M8 memiliki nilai similaritas $100 \%$. sampel M2 memiliki nilai similaritas $100 \%$ dengan Sardinella lemuru MBCSC. Hasil analisa didapatkan Jarak genetic terjauh diantara skuen Sardinella lemuru di perairan Selat Bali sebesar 1,9\% yaitu pada sampel K5 dengan M8 dengan nilai similaritas keduanya yaitu $98,1 \%$. Dari hasil dapat diketahui bahwa ada $27 \%$ dari 11 sekuen sampel Sardinella lemuru di perairan Selat Bali mempunyai kemiripan 100\% dengan Sardinella lemuru Filipina 2 dan Taiwan 2. Sebanyak $9 \%$ sekuen lemuru mempunyai kemiripan $100 \%$ dengan sekuen Sardinella lemuru MBCSC. Nilai similaritas sebesar $100 \%$ menunjukkan bahwa spesies ikan lemuru di Selat Bali merupakan spesies ikan lemuru yang sama dengan ikan lemuru yang terdapat di Filipina dan selat Taiwan. Sofro (1994) menyatakan bahwa suatu populasi yang memiliki tingkat kedekatan hubungan kekerabatan yang tinggi mempunyai banyak persamaan morfologi, genetik dan dipengaruhi oleh keadaan lingkungan

Pohon filogenetik merupakan suatu metode untuk mengetahui tingkat evolusi dan kekerabatan suatu spesies. Spesies Sardinella lemuru yang memiliki rantai DNA yang mirip akan membentuk suatu cabang yang berdekatan dan akan membentuk satu kelompok yang besar (clade). Analisis filogenetik suatu spesies dapat dilakukan pada karakter morfologi dan gen-gen yang berada di dalam dan di luar tubuh dengan sekuen DNA mitokondria. Penggunaan sekuen DNA mitokondria memperjelas hubungan spesies secara evolusi yang kabur akibat variasi morfologi (Avise, 1994). Sekuen DNA mitokondria memperlihatkan variasi DNA suatu populasi, perubahan breeding suatu individu dan isolasi terhadap populasi tersebut (Liu et al., 2000; Tjong et al., 2007). Setelah dibandingkan antara 11 sekuen gen COI Sardinella lemuru di perairan Selat Bali dengan 7 sekuen gen $\mathrm{COI}$ Sardinella lemuru dan Sardinella longiceps dari Gen Bank menghasilkan pohon filogeni pada Gambar 2 yang dibuat dari program MEGA 5.2 berdasarkan algoritma neighbor joining tress dengan model evolusi Kimura2parameter (K2P). Hasil konstruksi pohon filogeni menunjukkan bahwa 11 sekuen gen COI lemuru dari perairan Selat Bali tidak berkelompok sesuai dengan daerah pendaratannya masing-masing, akan tetapi bercampur menjadi dua sub clad besar. Terdapat dua grup (clade) besar ikan Lemuru yaitu G1 dan G2, pada clade G2 terbagi menjadi 2 sub clade lagi yaitu sub clade G2A dan Sub clade G2B Dari pohon filogeni diketahui 11 sekuen gen COI Sardinella lemuru dari Selat Bali juga berkelompok menjadi satu sub clad besar dengan gen $\mathrm{CO}$ $S$. lemuru yang berasal dari China, Filipina, dan Selat Taiwan. Sedangkan subclad lainnya mengelompok hanya dengan lemuru yang terdapat di perairan Selat Bali yang kemungkinan besar merupakan berasal dari populasi yang sama. Hasil Ini menunjukkan bahwa ikan lemuru yang berada di perairan Selat Bali merupakan dari jenis Sardinella lemuru dengan nilai jarak genetik $<0.019$. Skuen Sardinella longiceps yang digunakan sebagai outgroup membentuk subklad yang berbeda dengan sampel $\mathrm{S}$. lemuru dengan jarak genetik $\geq 0.019$. Hal ini sesuai dengan dengan pernyataan Hebert (2003) bahwa jarak genetik berdasarkan sekuen gen $\mathrm{CO}$ lebih dari 0.02 merupakan spesies yang berbeda. 


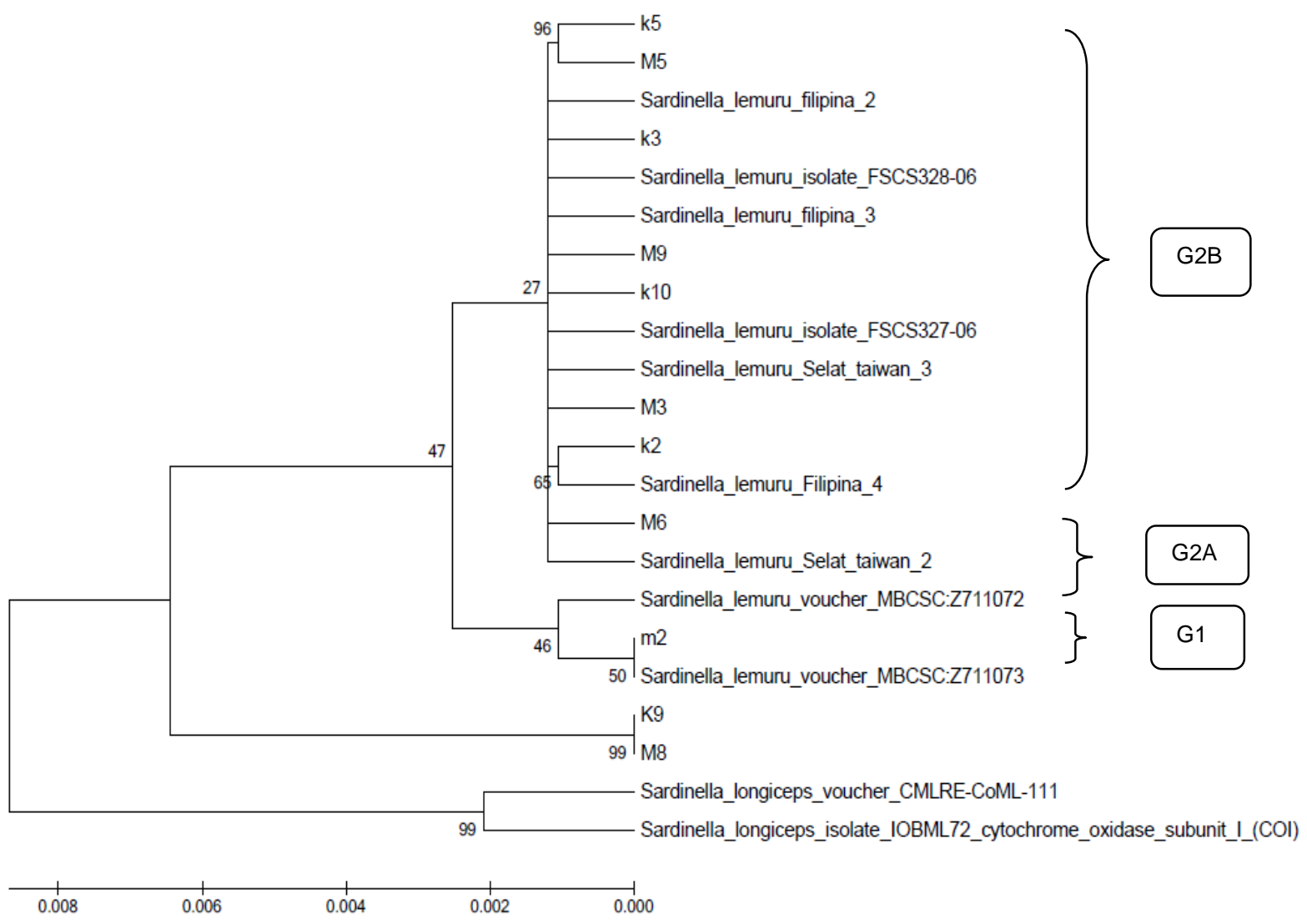

Gambar 3. Pohon Filogeni Sardinella lemuru. Menggunakan Sekuen Gen COI. Konstruksi Pohon Filogeni Berdasarkan Algoritma Neighbour Joining Tree Dengan Model Evolusi K2P (Bootstrap 1000x Pengulangan).

Pada clade Sardinella lemuru membentuk beberapa kelompok percabangan yang mengindikasikan bahwa terdapat populasi yang berbeda pada clade Sardinella lemuru. Skuen M2 terlihat berada di luar percabangan yang mengindikasikan individu ini berasal dari populasi yang berbeda dengan yang lainnya. Skuen K5 dan M5 berada pada satu cabang yang sama dan berdekatan, yang menunnjukkan kedua individu ini memiliki kekerabatan yang sangat dekat. Pada skuen K9 dan M8 terlihat berada pada percabangan berbeda pada clade Sardinella lemuru lainnya yang menunjukkan individu ini memiliki jarak genetik terjauh dengan yang lainnya.

Kekerabatan genetik yang dekat antara ikan lemuru di perairan selat bali dengan ikan lemuru yang terdapat di perairan filipina, laut china selatan, laut china dan selat Taiwan salah satu penyebab persebaran lemuru sendiri diduga dipengaruhi oleh adanya Arus lintas Indonesia (ARLINDO). Arlindo adalah aliran massa air yang membentuk arus laut pada wilayah perairan Indonesia dari Utara yang berasal dari Samudera Pasifik, menuju ke Selatan ke Samudera Hindia (Rizal, 2015) (Gambar 4). Faktor ini yang mengakibatkan terjadinya percampuran genetic antara ikan lemuru diperairan selat bali dengan ikan lemuru didaerah lain, karena ikan lemuru mengikuti arus arlindo untuk mencari makanan.Ini sesuai dengan pernyataan Tomascik et al., (1997), Ketika melewati perairan Indonesia, maka massa air Arlindo akan bercampur dengan massa air lainnya, sehingga terjadi percampuran massa air dari dua Samudera yang berbeda. Sebagai salah satu jalur arlindo, perairan ini kaya akan nutrien penting bagi kehidupan fitoplankton. Dalam rantai makanan, fitoplankton akan dimakan ikan kecil dan kemudian oleh ikan besar. 


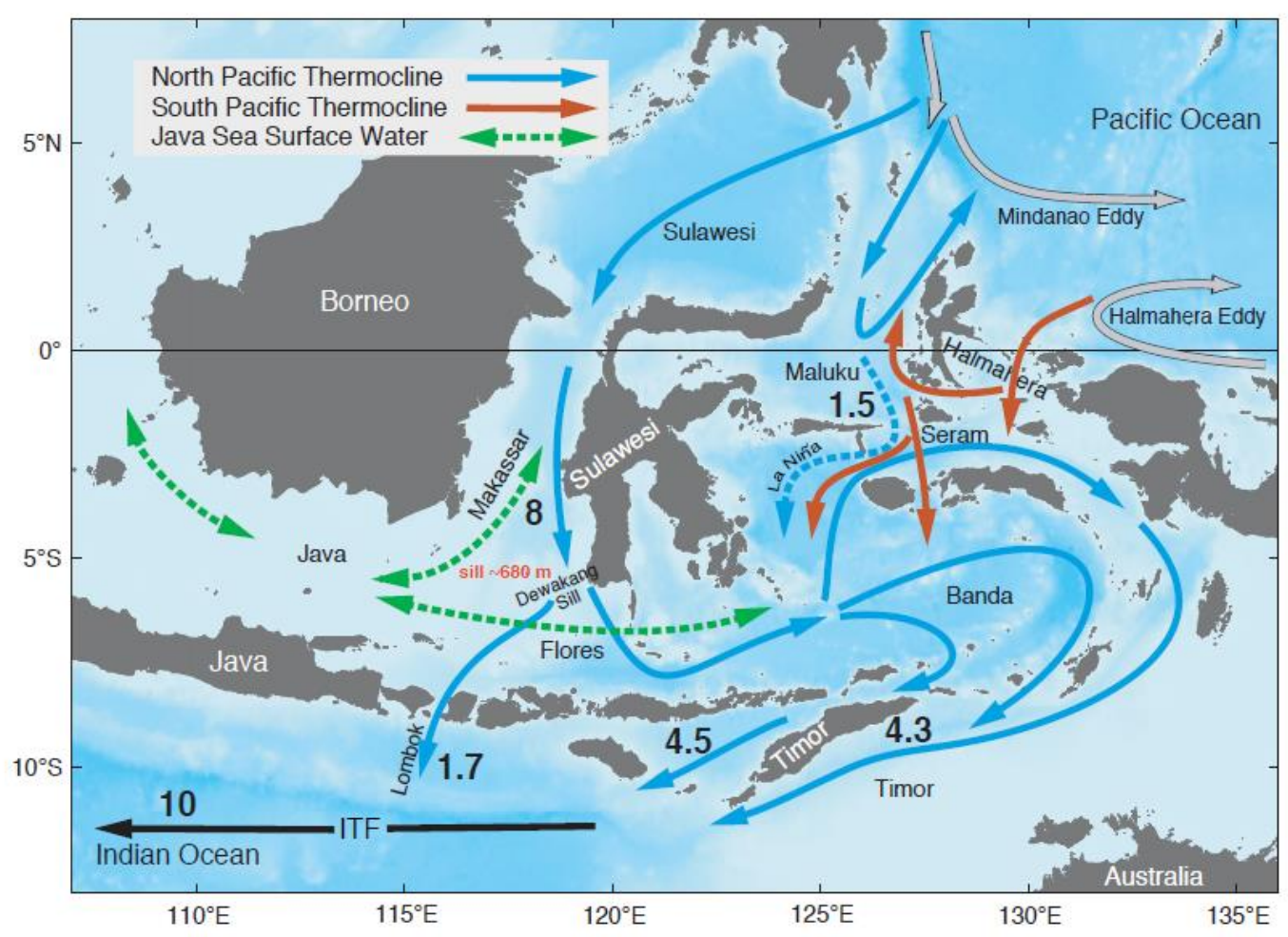

Gambar 4. Arus Lintas Indonesia (ARLINDO) (Gordon, 2005)

\section{KESIMPULAN}

Hasil analisis genetik mitokondria 11 skuen yang diperoleh dari Muncar Banyuwangi dan Kedonganan, Badung, teridentifikasi sebagai Sardinella lemuru berdasarkan Gen COI, dengan panjang amplikon sebesar $650 \mathrm{bp}$. Berdasarkan analisis gen COI Variasi genetic Sardinella lemuru di perairan Selat Bali masih tergolong tinggi. Sardinella lemuru di perairan Selat Bali memiliki hubungan kekerabatan genetik yang dekat dengan Sardinella lemuru yang terdapat di perairan Laut Cina Selatan, Selat Taiwan, Filipina dan Cina. Kedekatan secara genetic, ini diduga akibat pengaruh dari Arus Lintas Indonesia (ARLINDO).

\section{TERIMA KASIH}

Penulis mengucapkan banyak terima kasih kepada segenap staf dan peneliti di Laboratorium Biomolekuler fakultas MIPA Universitas Brawijaya Malang, kelompok nelayan di Muncar, Banyuwangi dan Kedonganan, bali yang telah membantu dalam mengumpulkan sampel ikan lemuru yang digunakan
DAFTAR PUSTAKA

Ausubell, F. M, Brent, R., Kingston, R. E., Moore, P.D., Seidemen, J. G., Smith, J. A., \& Struhl, K. (2002). Short Protocols in Molecular Biology, Fifth Edition. John Willey and Son Inc. Canada

Avise, J. C. (1994). Molecular Marker, Natural History and Evolution. Chapman and Hall. USA

Buhay, E. (2009). "COI-Like" Sequences Are Becoming Problematic In Molecular Systematic And DNA Barcoding Studies. University Of South Carolina

Costa, F. O., de Waard, J. R., Boutillier, J., Ratnasingham, S., Dooh, R. T., Hajibabei, M., \& Hebert. P. D. N. (2007). Biological Identifications through DNA Barcodes: The Case of Crustacea. Canadian J. Fish. \& Aqua. Sci., 64(2), 272-295. doi: 10.1139/f07-008

Divya, P., Gopalakrisna, A., Jhon, L., Thomas, P.C., \& Cakra, W. S. (2009). Mithocondrial DNA (Cythocrome C Oxidase I) Sequencing of Indian Marine 
Mussels. Indian J. Fish., 56(3), 223226.

Dunham, R. A. (2002). Aquaculture and Fisheries Biotechnology: Genetic Approach. New York: CABI Publishing, Cambridge. pp 85-99

Gordon, L. (2005). Oceanography of the Indonesian Seas and Their Through flow. Oceanography, 18(4).

Hebert, P. D. N., Cywinska, A., Shelley, L., \& de Waard, J. R. (2003). Biological Identifications Through DNA Barcodes. Proc. R. Soc. Lond., 270.

Hebert, P. D. N., Ratnasingham, S., \& de Ward, J. R. (2003). Barcoding Animal Life Cytochrome C Oxidase Divergences Among Closely Related Species. Proc. R. Soc. Lond., 270.

Jonas, P. Q., Brian, S., Santos, P., Ong., Zubaida, U., Basiao., Ian Kendrich, C., Fontanilla, \& Cao, E. P. (2011). DNA Barcoding of the Philippine Endemic Freshwater Sardine Sardinella tawilis

(Clupeiformes: Clupeidae) and Its Marine Relatives. Philipp. Agric. Scientist, 94(3), 248-257.

Liu, W., Lathrop, A., Fu, J., Yang, D., \& Murphy, R. W. (2000). Phylogeny of East Asian Bufonids Inferred from Mitochondrial DNA Sequences (Anura: Amphibia). Molecular Phylogenetics and Evolution, 14(3), 423-435.

Nei, M., \& Kumar, S. (2000). Molecular Evolution and Phylogenetics. Oxford University Press, New York.

Noor, R. (2008). Genetika Ekologi. Laboratorium Genetika Ternak. Institut Pertanian Bogor

Rizal, F., Setiyo, W., Pratomo, Y., dan Andri, E. (2015). Identifikasi Komponen Harmonik Di Selat Lombok Berdasarkan Data Arus Time Series. Depik, 4(1), 24-32.

Sofro, A. S. M. (1994). Keanekaragaman Genetik. Yogyakarta: Andi Offset. 127 hal

Susilo, K. (2015). Variabilitas Faktor Lingkungan Pada Habitat Ikan Lemuru Di Selat Bali Menggunakan Data Satelit Oseanografi Dan Pengukuran Insitu.
Tjong, D. H., Matseu, M., Kuramoto, M., Belabut, D. M., Sen, Y. H., Nishioka, M., \& Sumida, M. (2007). Morphological Divergence, Reproductive Isolating Mechanism and Molecular Phylogenetic Relationship, Among Indonesia, Malaysia, and Japan Populations of the Fejervaria limnocharis Complex (Anura, Ranidae). Zoological Science, 24, 1197- 1212.

Tubaro, P., \& Lijtmaer, D. A. (2002). Hybridization Patterns and The Evolution of Reproductive Isolation in Ducks. División Ornitología, Museo Argentino de Ciencias Naturales 'Bernardino Rivadavia' Buenos Aires, Argentina. Biological Journal of the Linnean Society, 197-200

Tomascik, T., Mah, A. J., Nontji, A., Moosa, M. K. (1997). The ecology of Indonesian seas. Part I, Periplus Editions Ltd., Singapore

Wijana, I. M. S., \& Mahardika, I. G. N. (2010). Struktur Genetik Dan Filogeni Tuna Sirip Kuning (Thunnus albacares) Berdasarkan Sekuen DNA Mitkondria Control Region Sitokrom Oksidase I Pada Diversitas Zone Biogeografi. Jurnal Bumi Lestari, 10(2): $270-274$.

Zhang, J. (2011). Species Identification of Marine Fishes in China with DNA Barcoding. Evidence-Based Complementary and Alternative. Medicine, Article ID 978253, 10 pages. 